\title{
Legal Politics to Build a State of Happiness: An Idea in a State Based on the 1945 Constitution
}

\author{
Marojahan JS Panjaitan
}

\section{Department of Law, Bandung Law School, Indonesia}

\begin{abstract}
This research was conducted with the intent and purpose of answering two problem formulations, namely: what caused Indonesia to lag behind other countries, and secondly, how the legal politics in developing a country of happiness in Indonesia. The research method uses the method of legislation approach and comparison with literature studies. Based on research, several factors that cause Indonesia to lag behind other countries, namely: convoluted bureaucratic culture, a state administration that is not responsive to the needs of society, a national education system that is unable to produce quality graduates, unstable political conditions, Corruption, Collusion, and Nepotism are rife, and the development of primordial identity politics. Legal politics in developing a state of happiness is based on the purpose of a state based on the 1945 Constitution, namely: realizing a state of happiness. That is the idea of a state that must be realized in the life of the state in Indonesia which is mandated by the country's founders. Various efforts have been made in realizing this, but until now have not given satisfactory results. Indonesia is still far behind other countries. Of the 156 happiest countries chosen, Indonesia ranks 92. That means the government has not succeeded in giving happiness to its people.
\end{abstract}

Keywords: Law, State of Happiness, Political Law.

\section{INTRODUCTION}

If observed, the concept of the state of happiness is a form of shift (evolution) from the welfare state's idea, as an idea of a state which has been around for a long time. The concept of the welfare state arises because of the classical rule of law (formal and material law states), it was thought to have failed to create people's welfare (Panjaitan, 2018). However, at this time, the welfare state concept began to shift into a state of happiness. The shift occurred because of the rapid progress of science and technology, where the advancement of science and technology is directed to make people happy. For this reason, at present, almost all countries of the world do not merely create prosperity within the state. More than that, the state seeks to create happiness for its people. The international community also supports the idea of building this country of joy. The sustainable development program evidenced this, Sustainable Development Goals (SDGs), 21 October 2015, which the international community initiated as a substitute for the Millennium Development Goals (MDGs). The goal to be achieved in the SDGs is to create happiness for humans everywhere on this earth. Of the 156 world countries studied, ten countries have been named the happiest nations, namely: Finland, Denmark, Norway, Iceland, the Netherlands, Switzerland, Sweden, New Zealand, Canada, and Australia. Indonesia ranks 92th.

*Address correspondence to this author at the Department of Law, Bandung Law School, Indonesia; Tel: +6281394562558;

E-mail: marojahan1.jurnal@gmail.com
In Indonesia, the idea of building a country of happiness arises when the founders of the state, gathered in BPUPKI, want to formulate the 1945 Constitution as the basis of the state. The idea emerged based on Indonesia's experience when it was colonized by the Dutch, who lived in injustice and marginalized in all development. After Indonesia gained its independence, such a thing could not happen. All citizens have the right to justice and prosperity. When the state can provide justice and welfare to its people, its people must be happy. That is the idea of a condition that is to be built based on the 1945 Constitution, namely: creating a state of happiness. This was concluded from the fourth paragraph of the opening of the 1945 Constitution which states that the task of the state is to "advance public welfare" and "realize a social justice for all Indonesian people". These two words are often interpreted that the concept of a state built based on the 1945 Constitution is a welfare state. Thus, in various writings and discussions, it is always said that the idea of a state based on the 1945 Constitution is a welfare state. For example, Riwanto (2017) noted in his writings that from the beginning, Indonesia had embraced the concept of a welfare state in its basic constitution (the 1945 Constitution). The same thing was stated by Bisaryadi (2016) by saying that the 1945 Constitution mandated the state to meet the prosperity of the people and organize social welfare. Setiyono (2018) also noted that the Indonesian constitution clearly states that the state was established with one of its main objectives being to realize public interest (social welfare). Panjaitan (2017) previously also thought that 
Indonesia, based on the 1945 Constitution, adheres to understanding the welfare state law.

Various opinions that state that Indonesia is a welfare state cannot be faulted. That opinion appears influenced by the concept of the welfare state that developed before. If observed the purpose of the state, as mentioned in the 1945 Constitution, is happinessthe founders of the state-mandated the condition of giving pleasure to all the people of Indonesia.

The determination to build this country of happiness from the beginning of independence until now continues to be done. At the beginning of freedom, President Sukarno began to reform the government system. It was not easy at that time, because Indonesia was just independent, and the Dutch did not want to let Indonesia go. In the New Order government, the development program compiled in the Broad Guidelines of the State Policy (GBHN) was directed at achieving national welfare. After the reformation, changes were made to the 1945 Constitution, by giving the president more freedom as government head. The functions of the government that were formerly under the MPR, after the changes, are equal so that the president can freely carry out development. In supporting a clean government and combating corruption, a law was issued.

No. 28 of 1999 concerning Clean State Administration, Law. 31 of 1999 concerning Eradication of Corruption Crimes. As a basis for development, a law was issued. No. 17 of 2007 concerning the LongTerm Development Plan 2005-2025. Likewise, in managing the government, a decree was issued. No. 5 of 2014 concerning State Civil Apparatus, Law. No. 23 of 2014 concerning Regional Government, Law. No. 30 of 2014 concerning Government Administration, Presidential Regulation Number 81 of 2010 concerning Grand Design of the 2010-2025 Bureaucracy Reform, Presidential Regulation Number 95 of 2018 concerning Electronic-Based Government Systems, Government Regulation Number 30 of 2019 concerning Performance Evaluation of Civil Servants and so on. All development efforts are carried out in the framework of bringing happiness to all the people of Indonesia. However, development in realizing happiness in the community has not produced satisfying results. Indonesia is still far behind other countries. This was proven, from Indonesia's rank, which still ranks 92 out of 156 countries of the world studied. This is a fact that cannot be denied.
Based on the formulation of the problem stated above, there are two issues to be investigated: what causes Indonesia to lag behind other countries and how the legal politics in developing a state of happiness in Indonesia. Thus, this study aims to examine what causes Indonesia to lag behind other countries and understand and discuss how legal politics in developing a nation of happiness in Indonesia.

\section{METHOD}

Following this study's objectives, the research specifications are descriptive research, which is done by giving an overview or description of the problems in this study. Furthermore, the research method is adjusted to formulate the question that is the focus of this study. On that basis, this type of research is normative legal research. The data examined are secondary in the form of primary standard materials and traditional secondary materials. As a consequence of normative legal analysis, this study uses the conventional approach and comparison method. The material is then processed and analyzed qualitatively in the form of words and not in the form of numbers.

\section{RESULTS AND DISCUSSIONS}

\section{Factors That Cause Indonesia behind Other Countries}

As stated earlier, in a world that has changed due to the rapid development of science and technology, Indonesia is still far behind other countries. Indonesia is still considered a developing or underdeveloped country. If seen from its age, which has reached 74 years, Indonesia should have been more advanced than other countries coupled with its rich natural resources.

The two countries have rich natural resources, namely; Indonesia and Ghana, but these two countries are still categorized as poor or underdeveloped countries. In contrast, Singapore, South Korea, Japan, and Switzerland are low in natural resources. Nevertheless, these countries have succeeded in increasing their people's welfare, so they are called developed countries. Singapore has no natural resources, but they are very advanced, far beyond Indonesia and Ghana. This can be seen from Indonesia's per capita income of US \$ 3,927 or around Rp. Fifty-six million per capita per year in 2018, while Ghana's per capita GDP is US $\$ 1,807.10$ per year. 
Compare this to the per capita Gross Domestic Product (GDP) of Singapore reaching 58,247.90; Malaysia in 2018 amounting to $11,079,266$ USD, Thailand in 2018 amounting to USD $7,605,783$, South Korea $26,761.90$ USD; Japan 48,919.60 USD, and Switzerland 78,816.20 USD in December 2018 (Trading Economic, 2019).

According to data from The Inclusive Development Index 2018: Summary and Data Highlights published by the World Economic Forum from 77 assessed countries, Indonesia ranks 36th in the Emerging Economies standings with an overall score of 3.95, IDI general trend for five years of $2.57 \%$, Vietnam ranks 33 , with an overall score of 3.98 , overall IDI trend for five years $-1.34 \%$; Thailand ranks 17 th with an overall score of 4.24 , overall IDI trends for five years $1.93 \%$; Malaysia ranks 13th in the Emerging Economies standings, with an overall score of 4.30 , a 5 -year general IDI trend of 2.40\%; and for Ghana ranked $52 \mathrm{nd}$, with an overall score of 3.34 , overall IDI trends for five years $-1.67 \%$. In the Advanced Economies standings, of the 30 countries assessed, Norway ranks first, with an overall score of 6.08 , the general trend of IDI for five years $-0.77 \%$, the Republic of Korea ranks 16 th with an overall score of 5.09 , the overall direction of IDI for five years $2.20 \%$. Japan ranks 24 th with an overall score of 4.53 , the general trend of IDI for five years, 1.14\% (World Economic Forum, 2018).

Some data, as stated above, prove that Indonesia is still far behind other countries. Indonesia is still in poverty. Azhar Kasim said that three factors caused Indonesia to lag and were challenging to get out of the slump, namely:

First, bureaucratic culture is a barrier to progress, as there are still many values, beliefs, and cultural norms that are less conducive to development efforts. For example the decline in the value of integrity (honesty), lack of meritocracy (the best use of talent), very rule-driven behaviour rather than mission-driven, less respect for efficiency, a decline in the value of nationalism, and increased particularistic orientation (such as ethnicism orientation, religious fanaticism, and conflict), and the still-dominant linear mindset and maintaining the status quo rather than a dynamic perspective that wants a holistic change.

Second, the state administration is not responsive to the community's needs, such as convoluted service procedures, top-down approach without program evaluation and feedback. The government and its officials prefer reports on the implementation of government agencies' performance (LAKIP) made by the leaders of the agencies concerned rather than evaluating the performance of institutions by stakeholders. Besides, the low level of welfare of civil servants is suspected of influencing bureaucrats' behaviour; for example, it is easy to be tempted to corrupt practices, especially if there are opportunities and weak supervision systems.

This situation is exacerbated by a weak national education system, unable to produce quality graduates as innovative knowledge workers who drive national development. Although globalization enables excellent integration between countries in the world, as a result of falling costs of communication, transportation, reduced barriers to the flow of goods, services, capital money, ideas, and knowledge, it turns out that only developed and wealthy countries can take advantage of the opportunities it poses. As for developing countries like Indonesia, globalization is perceived more as a threat than an opportunity.

What was stated by Kasim (2015) above is a fact that cannot be denied to occur in Indonesia. We can see corruption, collusion, and nepotism practices carried out without shame by state officials, political elites, and business people in front of our eyes. The building's quality is low, so it is easily damaged, and many construction projects are stalled. The state's wealth (money) is only enjoyed by a handful of political elites, state officials, and business people who are close to the political elite and state officials, while the ordinary people fall into poverty, misery, and suffering.

Likewise, the bomb terrorist acts carried out by radical groups (terrorism) also significantly disrupt the Indonesian economy. This opinion is consistent with what was said by Francis and Heliati (2019) that one of the motives of terrorism is to threaten the economic sector. The attack carried out can result in damage and death and further curb economic growth through several indicators. Terrorism can increase the costs of doing business, such as insurance premiums and high salaries.

What is said by Michael Francis and Ratni Heliati is true. This was proven by the suicide bombing in Legian Bali, Saturday, October 12, 2002, which claimed many innocent victims. Likewise with the bomb terrorist acts at the JW Marriot and Ritz Carlton hotels on Friday, July 17, 2009, Jakarta, the Australian Embassy Bombing, September 9, 2004, Bali Bomb II, October 1, 
2005, Sarinah Bombing, January 14, 2016, 3 churches in Surabaya in bombs on May 13, 2018, the night of May 13,2018 , there was a bomb at the Wonocolo flats in Sidoarjo, May 14, 2018 bombs exploded again in Surabaya Mapolres, and on May 16, 2018, bombs exploded again at Riau Regional Police Headquarters. All claimed no small number of victims, and not a small amount of state money was spent tackling this radical group's actions.

This bombing action caused the tourism industry to be destroyed because many foreign tourists cancelled their intention to travel to Indonesia. It can be known from a report from The Indonesian Institute's Center for Public Research (2016) that after the 2002 Bali Bombing, the 2004 JW Marriot Bomb, the 2004 Australian Embassy Bomb, and the 2005 Bali Bombing II, where the growth of the tourism industry declined dramatically due to suicide bombings the. For example, in the Bali Bombing II incident, the development of hotel and tourism performance decreased by $2 \%$ to $6 \%$. Mahagangga et al. (2012), also said that after the Bali Bombing I and II there was a significant decrease in tourist arrivals on holiday to Bali. A very substantial reduction in 2003 was almost $23 \%$ due to the Bali Bombing I, and in the Bali Bombing II, the decrease reached nearly $10 \%$.

Investment has also been hampered because many investors have withdrawn their shares and transferred them to other countries, and many have cancelled their investment in Indonesia. In her research, Carissa Cindy (2017) said that in the Bali Bombing I incident on October 12, 2002, the abnormal return immediately dropped sharply from the previous day, worth 0.013 , to -07474. The day after the event, there was a lot of abnormal return increase to 0.008 . Likewise in the Sarinah bombing of January 14, 2016, Handoko and Supramono (2017), said that there was a negative sentiment over the Sarinah bombing incident on January 14, 2016, against shares in the LQ45 and PEFINDO25 stock indexes.

Lately, there is a political elite group that justifies any means to gain power by collaborating with a group of scholars who are suspected of supporting ISIS, developing primordial identity politics. Primordial identity politics is a political system that evaluates or treats people differently because of different ethnicities, religions, and creeds, and groups (native and nonnative). This primordial identity politics is similar to the political system of racism (apartheid) developed in the era of colonialism in the past. The international community is very opposed to this primordial identity politics because it is considered contrary to human rights, but it was even developed in Indonesia.

This group of ulama supporters of primordial identity politics has its mission: wanting to replace the basis of the Pancasila state and the 1945 Constitution with their ideology. They want to establish a Khilafah state in Indonesia. This group also thinks that those who are not compatible with them, even if they are religious are considered enemies. One of the mass organizations supporting this primordial identity politics is Hizbut Thahir Indonesia (HTI). HTI in 2013 in Jakarta, openly declared the establishment of a Khilafah state in Indonesia. At that time, HTI openly raised its flag and stated that it rejected Pancasila and the 1945 Constitution. Of course, this kind of thing was awful for the country's survival and could lead to national disintegration.

The development of primordial identity politics can be seen clearly in every general election of regional heads, presidential elections, and education (ranging from the primary, secondary and higher education), State-Owned Enterprises and Regional-Owned Enterprises, political parties, organizations society, and also in state offices. In the 2017 DKI Jakarta Governor election, the 2018 North Sumatra Governor election, and the previous 2019 Presidential Election, for example, can be seen how the primordial identity politics were explicitly and openly used as a tool to win the election. Until someone invites Uhud war, Badar war, martyred in winning the election. The issue of hoaxes was developed in bringing down opponents. The point of frauds is for example, what was done by three women in Karawang regency, who went around spreading "if Jokowi wins the call to prayer will be abolished". A callous way, because how is it possible Jokowi-Ma'ruf Amin who is Muslim will negate the call to prayer.

It is undeniable that it is shrouded in political transactions between candidates and political elites in primordial identity politics and supporting religious leaders. Selected candidates will try to return the favour by dividing the government seat and sharing the project with its supporters. The oversight function is not functioning, and instead, they will work together for corruption. In the end, corruption will flourish, and many projects are stalled and of low quality. Gradually, this ulama group will replace the Pancasila state's foundation with the ideology they believe in. This causes political stability to be disrupted. As a result, the 
level of trust in Indonesia's investment world has diminished, resulting in stunted economic development.

The development of primordial identity politics will ultimately lead to social injustice and social inequality. Asshiddiqie (2018) argues that social injustice is related to the notion of injustice (in fairness) in the distribution of resources, opportunities, responsibilities, violence, and oppression in all its forms, as well as all things that prevent people from exercising their right to self-determination and realizing full potential. That is, social injustice occurs when a person, in his life anywhere, is treated in an inhumane, unfair way, does not have the resources needed in life (such as clothing, food, housing), does not get a chance (such as political freedom, opportunity work), which he should be able to enjoy.

Social injustice occurs in getting positions in the state. An example is Basuki Tjahaya Purnama (Ahok), who has rejected as the Governor of DKI Jakarta because he was Christian and of Chinese descent. Everything was done to prevent Ahok from becoming the Governor of DKI. Ahok is an Indonesian citizen who was born in Indonesia. He is a leader of high integrity who has succeeded in developing Jakarta. At the time of this writing, the Banten Provincial Ulema Council rejected the new Banten Regional Police Chief's inauguration, which was determined by the National Police Chief because it was a Christian. This rejection is undoubtedly contrary to Article 27 paragraph (1) Jo Article 28D paragraph (3) of the 1945 Constitution, which guarantees that every citizen has the same opportunity in government. Likewise, in worship, minority groups are often hampered in establishing places of prayer and worship. Let alone to show, even those who have already been standing are forcibly closed, bombed, and burned. Insult to minority religions is rampant, in the form of what they say is "infidel". This is undoubtedly contrary to Article $28 \mathrm{~J}$ paragraph (1) Jo Article 28I paragraph (2) Jo 29 of the 1945 Constitution which guarantees the right of all citizens to embrace religion and practice worship following their religion.

A country that claims to be democratic should look at the common interests and not rely on the majority and minority. The new decision is considered democratic if all citizens' rights are protected, or no one is harmed (Panjaitan, 2018). All in the country have the same rights before the law and government. Following what Barak (2006) said, in a democracy, all have the same rights. Democracy aims to protect human rights. Wolin (2008), then says, "The idea of a democratic political culture was about cooperating in the care of common arrangements, of practices in which, potentially, all could share in deciding the use of power while bearing responsibility for their consequences".

Listening to Wolin's opinion, it appears that in a democratic political culture cooperation is developed in managing shared interests. If this is related to Barak's statement, then the political culture must be directed to build a common interest without being more critical. Both the majority and minority have the same rights in obtaining legal protection, justice, and welfare. Let different ethnic groups and religions, and we are Indonesia. This is actually what should be highlighted if Indonesia wants to progress. If this is not established, social injustice will occur, which leads to social inequality. This opinion is consistent with what Asshiddiqie said (2018) that social injustice in turn causes social inequality to be more fertile in the structure of life in society and affects all people with various types and forms, such as: 1) Inequality of wealth distribution, i.e. comparison of wealth among people community members or among groups and groups in the community; 2) Discrimination, i.e. unfair treatment of people or something by applying different standards to the same subject or object, which is just as unjust as using the same standard to other residents or entities; 3) Discrimination based on SARA (ethnicity, religion, race and intergroup), that is, evaluating or treating people or groups of people differently because of different tribes, religions and beliefs, race (racism), or class; 4) Prejudice, which is a judgment / positive / negative attitude towards a person or group of people based on beliefs and beliefs, not based on facts; 5) Sexism, which is discriminatory treatment because gender is mainly due to women (because initially this was a form of discrimination directed explicitly against women); 6) Abeleism, namely discriminatory treatment of people with disability issues; 7) Ageism, namely discriminatory treatment of people based on their age, both because they are older and older; 8) Stereotyping, which is the assumptions or presuppositions we make about a group that is generalized on the basis of a negative assessment of just one or a few people from group members; 9) Oppression, i.e. the use of power or authority in cruel and inhumane ways. One of the most brutal forms of oppression known to humanity is genocide.

Through Asshiddiqie's opinion, it appears that in social inequalities, humans are treated unequally in obtaining legal protection, justice, and welfare, so that its people find it difficult to get happiness. In social 
inequality, disputes that can lead to riots and civil war can occur. That can be seen as is happening in some Middle Eastern countries today. Its people suffer, and many are displaced into refugees in other countries. Whatever the outcome, civil war will cause misery to humankind. Hopefully, this has never happened in Indonesia.

\section{Building a Country of Happiness}

\section{The State of Happiness According to the 1945 Constitution}

To understand what the state of happiness is, we first explain what it means to be happy. In Arabic happiness is sa'adah means "luck" or "happiness. In English happiness is called "happiness". In Sundanese, happy words are called "bungah" or "bagja". In Javanese happily it is called "rahayu", whereas in Batak it is called "Gabe". In the Big Indonesian Dictionary, happiness comes from the word happy. Happiness is defined as a state or feeling of pleasure and peace (free from all that is troublesome), while joy, is defined as the pleasure and relaxation of life (inner and outer). In various writings, happiness is interpreted differently. For example, Putri (2018) said that satisfaction is a feeling and a state of physical and spiritual birth without any sense of anxiety. Pontoh and Farid (2015) concluded that happiness makes a pleasant experience in the form of feelings of pleasure, peace and also includes welfare, peace of mind, life satisfaction, and the absence of feeling depressed. All of these conditions are conditions of happiness felt by an individual.

Based on the meaning of happiness as stated above, it is true what Frey and Stutzer (2002) said that "Everyone wants to be happy". Denny JA (2017) also noted that everyone craves happiness even though he is in the middle of a hard life and struggling to live well. Rynbrandt (2016) mentions that one of Socrates, Plato, and Aristotle's main goals is "That of making happiness the goal of all human activity. These three spilt a lot of ink investigation of the causes, nature, attributes, and limits of joy. The problem is how to determine someone is called happy.

Determining someone to be called happy is certainly not easy, because as stated by Pontoh and Farid (2015), happiness is abstract and cannot be touched. So, many doses that make someone called happily. For example, some say, someone who is economically well off is often called a happy life.
In a household that always looks harmonious, the family is often called a happy family. When someone gets a vast lottery, graduates from school pass a job entry exam rises a position marries a loved one, and so on, they are called happy.

Wattimena (2015) says that a happy life means a life lived in the right way of thinking. Frey and Stutzer (2002) say people are so glad "... more often smiling during social interactions, and are rated as happy by friends and family members, as well as by spouses". Denny JA (2017) said that those happiest are surrounded by friends and live in a close community. The group of people who are the most unhappy live alone, or find it difficult to be friends and live far from the district.

In Islam, Hamda (2016) said that happiness covers two areas: worldly happiness and the afterlife. In the enjoyment of the world, it is felt through the emotion of excitement for achieving what is expected in the world, such as wealth, power, scientific success, and faith and holiness. The second happiness, that is, the enjoyment of the afterlife is not felt at this time, but is expected to be obtained later when the world's life has ended and is eternal. This is following the prayer most often read by Rasulullah SAW, namely: "Rabbana aatina fid dunyaa hasanah wa fil akhirati hasanah waqina azabannar" which means "O Allah, grant me world happiness and happiness in the hereafter and keep us away from the torments of hellfire.

As also explained by Hamda (2016) that according to Ali bin Abi Talib RA, the happiest people are those who leave temporary delights for eternal delights. The meaning of the Apostle's friends' words above can be interpreted that the leading indicator of true happiness is to prioritize the enjoyment of the hereafter above worldly pleasure. Therefore, it needs to be understood that Islam's perspective understands human behavior that shows obedience to religion as a characteristic of individuals who are happy in the world and the hereafter.

Furthermore, Hamda (2016) also explained that based on Ibn Abbas RA's view, a companion of the Prophet who was very obedient in protecting the Prophet Muhammad mentioned there are seven indicators of happiness according to Islam, namely: 1. Qolbun syakirun or a heart that is always grateful, 2. Al azwaju shalihah, that is, a pious life partner. 3. Al auladun abrar, namely a righteous child, 4. Al biah sholihah, an environment conducive to our faith, 5 . al- 
malul halal, or halal treasure, 6. Tafakuh fid dien, namely understanding religion, and 7. Barokatun general, namely the blessing age.

Happiness in the Christian viewpoint, Ginting (2018) refers to the Gospel of Matthew 5: 1-12 saying that the meaning and meaning of joy, not just what makes happiness. It is said, blessed are those who are inferior before God, who mourn, who are gentle, hungry, and thirsty for the truth, who are generous, who are pure in heart, who brings peace, and who are persecuted because of the fact. Happiness is human needs in the present and the future.

According to the teachings of Hinduism, as stated by Triguna (2018) that stressed the need to maintain a harmonious relationship with God, between humans, and human relations with their environment is called trihita-Kirana. Tri hita Karana means three causes of happiness. In essence, Hindu people are taught to maintain a harmonious relationship between themselves and God, with fellow human beings and the environment. Living in harmony is believed to be the base of peace, safety, and happiness.

In the Batak philosophy of life, parents feel delighted when they see their children succeed in their lives. So there is the phrase "anakkon hi do hamoraon di au" (my children are my happiness). Parents will be delighted to see all their children successful, married, and have children. In achieving this, parents work hard to make all their children successful. He did not care for the sake of fighting for his children's success. The success of his children is his happiness. All parents hope that he dies after all his children are thriving, have a family, and have children. So, when he died, he was called "saur matua". When he died, his children and grandchildren should not be sad. They are "manortor marembas" (dancing while having fun) to give thanks and thank God for giving their parents "gabe" (happy).

Frey and Stutzer (2002) mentions five determinants of someone called happiness, namely: 1) Personality factors, such as self-esteem, personal control, optimism, extraversion, and neuroticism; 2) Sociodemographic factors, such as age, gender, marital status, and education; 3) Economic factors, such as individual and aggregate income, unemployment, and inflation; 4) Contextual and situational factors, such as particular employment and working conditions, the stress involved at the workplace, interpersonal relations with work colleagues, relatives and friends, and most importantly-the marriage partner as well as living conditions and health; 5) Institutional factors, such as the extent of political decentralization and citizen's direct political participant rights.

Based on the description, it can be said that happiness is a condition where a person feels a happy, peaceful feeling. He can enjoy his life calmly without any pressure from anyone, and apart from the burden of thoughts that make him difficult. Indeed, it is not easy to determine someone is called happy, but everyone wants to live happily, both in this world and the hereafter. In social and state life, happiness is an ideal that must be fought together. The burden is given to the state through the government. Because the state is a social organization that regulates and administers a specific community in a permanent territory through a sovereign government.

Budiardjo (2008) says that the state establishes ways and boundaries to which power can be used in the state's life, both by individuals and groups or associations and by the state itself. Thus, the state integrates and guides the social activities of its population towards a common goal. Affandi (1982) mentions that the most fundamental needs whose fulfilment is to be achieved by humans by establishing a state, are: 1) Maintaining security and order in human life; 2) Maintaining the existence of people who cooperate and founded the country against attacks from outside that aim to disrupt or even destroy their survival; 3) The achievement of economic material prosperity and mental-psychological well-being of every individual member of the community in the country, as well as of the whole society collectively; 4) The implementation of justice for everyone in the country.

Budiarjo (2008) then mentions that there are two tasks of the state, namely: a) Controlling and regulating the symptoms of asocial power, that is, conflicting with each other, so as not to become a dangerous antagonism; b) Organizing and integrating human activities and groups towards achieving the objectives of the whole community. The state determines how the activities of all social associations. The state determines how social associations' actions are adjusted to one another and directed towards national goals.

There are also the functions of the state according to Budiarjo (2008), are a) Carry out the issuance (law and order); to achieve common goals and prevent clashes in society, the state must implement the order. It can be said that the state acts as a "stabilizer"; b) 
Promote the welfare and prosperity of its people. Today this function is considered very important, especially for new countries. This view in Indonesia is reflected in the government's efforts to develop through a series of Five-Year Development Plans; c) Defense; this is necessary to guard against possible outside attacks. The country is equipped with defence equipment; d) Uphold justice; this is done through court bodies. Suppose you pay attention to the goals, duties, and functions of the state as stated above. In that case, all lead to the protection of citizens' rights to live comfortably and comfortably in the framework of realizing happiness within the state. For a country that claims to be a state of law, the state carrying out its duties and functions is carried out under the law. The highest law in a country is the constitution.

\section{Political Law in Realizing a State of Happiness}

When talking about the politics of law, various literature found a variety of understandings. Wahjono (1986) said that the politics of law is a state administration policy about what is used as a criterion to punish something that includes the formation, application, and enforcement of the law. In the meantime, Mahfud MD (2012) said that legal politics is an official standard policy or policy line that will be enforced both by making new laws and by replacing old rules, in achieving the country's goals. Karianga (2013) also said that legal politics is an activity that determines the patterns and ways of shaping the law, overseeing the operation of the law, and renewing the law to achieve the goals of the country. Based on these three opinions, it appears that legal politics has a broad understanding, namely: covering the formation, implementation (enforcement), and legal reform.

In-state life in Indonesia, legal politics must be in harmony with the state's concept, as mentioned in the 1945 Constitution. The idea of form built based on the 1945 Constitution is the concept of a national state. That was concluded from the third and fourth paragraphs of the 1945 Constitution which mentioned several times the words "nationality" and the word "nation". This mention certainly has a legal meaning: that the state proclaimed on August 17, 1945, is a nation-state and not a primordial state of religion or ethnicity. As a nation-state, all citizens are considered a political entity with the same position, and the state should protect it (Panjaitan, 2018). Surbakti (2014) said that nationhood is an essential fundament of the political system of democracy. As a vital foundation for a democratic political system, the nation-state's concept must be obeyed in carrying out legal development in Indonesia.

Besides what was stated above, the provisions as mentioned in Article 1 of the 1945 Constitution also indicate that besides the nationality, Indonesia was also built in a unitary state in the form of a republic, with sovereignty in the people's hands the state based on law. The state concept is final and does not need to be debated and cannot be replaced with another because it was an agreement from the country's founders that must be obeyed by all the nation's successors. This is following what Soemantri (2014) stated, that the Basic Law as a formal document contains: a) The results of the nation's political struggle in the past; b) The views of national figures which are about to be realized, both for the present and future; c) A desire (will), through which the development of the life of the nation's state administration is to be led; $d$ ) The highest levels of development of the state administration.

The 1945 Constitution is a formal document that has been agreed upon by Indonesian freedom fighters, which is gathered in the Indonesian Independence Preparatory Investigation Body before independence and has been ratified to be the highest law in Indonesia. On that basis, the 1945 Constitution as a formal state document, then by following the opinion of Sri Soemantri, what has been stipulated in the 1945 Constitution must be obeyed. As an archipelago consisting of diverse ethnic groups, Indonesia all have the same right to enjoy happiness in the country. The concept of statehood must be the basis for implementing development in Indonesia.

It is known that development is a conscious effort made by humans to change their destiny for the better. This opinion is consistent with what was said by Abdullah (2014) that development is an effort to advance the country's life and its citizens by creating new facilities and infrastructure or developing existing ones to achieve new goals. Development is carried out on all aspects of human life and can be enjoyed by all people fairly and equitably regardless of ethnicity, and religion. The product must be carried out with careful and effective planning. The plan includes guaranteeing and protecting the regularity, smoothness, and the whole process. The development results can benefit the community as a whole and not be enjoyed by only a few people.

Kusumaatmadja (2004) said that developing countries are characterized by change. In these 
changes, various social problems and problems can occur. This is where a legal presence is needed so that changes happen in an orderly manner. Kusumaatmadja (2004) said that regular changes through standard procedures, whether in the form of legislation or judicial bodies' decisions, are better than irregular changes using mere violence. Thus, the legal relationship with development is a two-way relationship that influences each other. It can be said, law with the effect is like two different sides of a coin, but it cannot be separated. Following what was said by Kusumaatmadja (2004) further, because both change and order (or order) are twin goals of a developing society, the law becomes a tool that cannot be ignored in the development process. Sidharta (2016) then says that in the direction sought is the settlement within the framework of the applicable legal order, which is systemically structured to a certain degree, which guarantees stability and predictability, to realize certainty and fairness in society. Lee (2017) also said that the law is a "body of rules of action or conduct prescribed by controlling authority and having binding legal force or a specific direction or a set of rules binding on society members. Based on this, the law must be obeyed in carrying out development. As Jayus (2019) said, compliance with the law also means that there are no rights of others who feel disadvantaged or feel deprived of either by certain parties or by state authorities. Djatmiko (2018) said that the law could force citizens (who are citizens) to behave as instructed by state law.

Listening to what was stated, it appears that the law is used as an umbrella and guiding principle in the implementation of development. So that development can go well and give happiness to the community, legal institutions are needed that can protect the product. Especially in the rapid progress of science and technology, new traditional institutions will serve as a guiding principle in solving various problems and problems caused by the development. That needs attention based on the fact that many laws in Indonesia today are outdated. An example is the Criminal Code and the Civil Code of the Dutch colonial heritage, which is still in force, judging by the substance of which is very much behind. In that framework, legal politics is directed at supporting national development. As Djatmiko (2018) stated, the politics of law holds a significant control for realizing good governance to realize national development goals. These namely laws protect and prosper the people.

More specifically Isharyanto (2016) said, that in the framework of increasing the competitiveness of the nation, the politics of law in Indonesia directed the development of law to support the realization of sustainable economic growth; regulate issues relating to the economy, especially the business world and the industrial world; and creating investment certainty, especially law enforcement and protection. What Isharyadi said is true. For this reason, various legal products that have been felt as hampering economic development must be updated immediately. However, legal reform is aimed at economic growth and must be done for all aspects of life. It cannot be denied, and economic development does play an essential role in creating national happiness. However, economic growth cannot run well if it is not supported by adequate infrastructure, reliable human resources, good political stability, and good bureaucracy.

All of which must be built synergistically. Infrastructure, for example, is needed to sustain economic growth. Because, without adequate infrastructure, economic growth will be slow. If the transportation facilities and infrastructure are inadequate, the flow of goods from one region to another will be dead, and operational boarding will be high. As a result, prices are becoming more expensive, and goods arrive at their destination for a long time, which can cause goods to be damaged. It is true what Kasim said (2015), that one of Indonesia's factors that is difficult to get out of the slump is a weak national education system, which is unable to produce quality graduates as innovative knowledge workers as the drivers of national development.

This can be proven from the ranking of Indonesian universities in the world is still low. For this reason, the construction of educational facilities and infrastructure, starting from elementary, secondary, and tertiary levels needs to be carried out thoroughly. In this case, it is necessary to restructure education governance, by updating educational patterns, providing skilled teaching staff, increasing the income of teaching staff, providing adequate research funding, updating the curriculum, renewing and completing educational facilities and infrastructure, providing scholarships for sons -national daughters who excel to continue their studies to universities abroad that have good quality, as well as adjusting the substance of the curriculum that has been running with advances in science and technology. For example, the Law Faculty Curriculum needs to be updated and revised to science and technology's rapid progress. The reform needs to be done so that law faculty graduates can face and solve various problems and problems caused by the rapid 
advancement of science and technology. In the law faculty curriculum, it is necessary to develop robotic law, industrial law, industrial, administrative law, agricultural law, sea and land fisheries law, natural resource law, and the substance of the existing curriculum that need to be adjusted to the progress of science and technology. The same thing needs to be done at other faculties. This needs to be done to produce graduates with high ability, mastering technology, character, and integrity. A leader is not enough to understand religion, but he must understand science and technology's progress so rapidly. That ability can be obtained through good education.

The government bureaucracy also needs to be restructured so that it can work fast and straightforwardly. This is consistent with what Asshiddiqie (2005) said: the government's mindset, which has been laden with bureaucratic procedures, must be changed. A bureaucracy that is loaded with bureaucratic procedures will make services slow and potentially corrupt. One of the main factors causing Indonesia to lag behind other countries is very high corruption. It can be said, and people want to become officials in this country to enrich themselves through bribery. Therefore, reforming the bureaucracy is an urgent need in Indonesia to be released from the slump. In reforming this bureaucracy, Mutia et al. (2018) said that it requires the government to change its public involvement approach in policymaking.

Farazmand (2004) said that we need a leader who has innovation and creativity to build the country reasonably in realizing happiness for all people in the latest governance. A good government must have innovation and creativity on how to create happiness for its people. Innovation and creativity are necessary for a rapidly changing global world that must be faced with good managerial skills. Because with these changes, many problems must be immediately resolved. Restructuring governance is a necessity that needs to be done so that happiness in the country can be created.

\section{CONCLUSION}

Based on research, several factors cause Indonesia to lag behind other countries, namely: a complicated bureaucratic culture, a state administration that is not responsive to the needs of society, a national education system that is unable to produce quality graduates, unstable political conditions, Corruption, Collusion, and Nepotism are rife, and the development of primordial identity politics. Legal politics in developing a state of happiness is based on a state's purpose based on the 1945 Constitution, namely: realizing a state of joy. That is the idea of a condition that must be learned in the life of the state in Indonesia, which is mandated by the country's founders. Various efforts have been made in understanding this, but until now have not given satisfactory results. Indonesia is still far behind other countries. Of the 156 happiest countries chosen, Indonesia ranks 92. That means the government has not succeeded in giving happiness to its people.

\section{REFERENCES}

Abdoellah, Oekan S. Pembangunan Berkelanjutan di Indonesia Di Persimpangan Jalan. Jakarta: Kompas Gramedia, 2014.

Affandi, Muchtar. IImu-IImu Kenegaraan Suatu Studi Perbandingan. Bandung: Lembaga Penerbitan Fakultas Sosial Politik Universitas Padjadjaran, 1982.

Asshiddiqie, Jimly. Hukum Tata Negara dan Pilar-Pilar Demokrasi. Jakarta: Konstitusi Press, 2005.

. Konstitusi Keadilan Sosial. Jakarta: PT. Kompas Media Nusantara, 2018.

Barak, Aharon, The Judge in A Democracy. New Jersey: Priceton University Press, 2006.

Bisariyadi."Pergulatan Paham Negara Kesejahteraan (Welfare State) dan Negara Regulasi (Regulatory State) dalam Perkara Konstitusional."Jurnal Hukum Ius Quia Iustum Vol. 23 No. 4 (Oktober 2016). https://doi.org/10.20885/iustum.vol23.iss4.art1

Bismantara. "Economics Of Happines: Kajian Teoritis Bagi Pengukuran Alternatif Kesejahteraan Negara.” http://ejournal. stiesa.ac.id/file.php?file=jurnal\&id=6\&cd= 062173ff6adea6fb09c95f6d50001f6\&nam6 =05\%\&20bismantara.pdf. Diakses 3 Agustus 2019 .

Budiardjo, Miriam. Dasar-dasar IImu Politik. Jakarta: PT. Gramedia Pustaka, 2008.

CIEC Data. "Malaysia Pdb Per Kapita." https:// www.google. com/amp/s/www.ceicdata. com/id/indicator/malaysia/gdp-percapita/amp. Diakses 24 Agustus 2019.

Departemen Pendidikan Nasional. Kamus Besar Bahasa Indonesia. Edisi Ketiga. Jakarta: Balai Pustaka, 2005.

Detik Finance. "Pendapatan per Kapita RI Naik jadi Rp 56 Juta per Tahun." https://finance. detik.com / berita-ekonomi- bisnis /d4415935/pendapatan- per-kapita-ri-naik-jadi-rp-56-juta- pertahun. Diakses 5 Agustus 2019.

Detik Travel. "Daftar Negara Paling Bahagia di Dunia 2019, Indonesia Nomor Berapa?."https: // m. detik .com/travel/travel-news/d-4477708/daftar- negara-palingbahagia-di- dunia-2019- indonesia -nomor- berapa. Diakses 7 Agustus 2019.

Djatmiko, Wahju Prijo. "Paradigma Pembangunan Hukum Nasional yang Responsif Dalam Persfektif Teori J.H. Merryman Tentang Strategi Pembangunan Hukum." Jurnal Arena Hukum Vol. 11 No. 2 (Agustus 2018). https://doi.org/10.21776/ub.arenahukum.2018.01002.10

Farazmand, Ali. "Sound Governance in the Age of Globalization: A Conceptual Framework". on Ali Farazmand (ed).Sound Governance: Policy and Administrative Innovations. Westport, Connecticut, London: Praeger Publishers, 2004.

Fransiskus, Michael dan Ratna Heliati, Heliati. "Keterkaitan Antara Terorisme Dengan Pertumbuhan Ekonomi di Indonesia Tahun 1985-2017." JIEPVol. 19 No. 1 (Maret 2019). 
Frey, Bruno S. and Alois Stutzer. "Happiness, Economiy and Institutions," Forthcoming in the Journal 110(466) (tanpa bulan terbit: 2000). https://doi.org/10.1111/1468-0297.00570

."The Economic of Happiness. "Jurnal World Economics Vol.3 No. 1 (Januari-March 2002)

.Happiness \& Economics: How The Economy and Institutions Affect Well-Being. Princeton, New Jersey: Princeton University Press, 2002

F, Carissa Cindy. "Reaksi Harga Saham di Pasar Modal Indonesia Terhadap Peristiwa Teror Bom Periode 2002-2017." Jurnal Akuntansi Universitas Jember Vol. 15 No. 2 (Desember 2017) https://doi.org/10.19184/jauj.v15i2.6882

Ginting, Baskita. "Kebahagiaan Orang Percaya: Refleksi Teologis Matius 5:1-12." ILLUMINATE Jurnal Teologia dan Pendidikan Kristiani Vol. I No. 1 (Juni 2018).

Hamdan, Stephani Raihana. "Happiness: Psikologi Positif versus Psikologi Islam." Jurnal Unisia Vol. XXXVIII No. 84. Januari 2016.

Handoko, Wina Meilia Waspadiana dan Supramono. "Sentimen Investor Terhadap Peristiwa Terorisme Berbasis Fundamental Perusahaan (Studi pada Peristiwa Serangan Bom Sarinah 14 Januari 2016)." Jurnal Akuntansi dan Keuangan Vol. 19. No. 2 (November 2017). https://doi.org/10.9744/jak.19.2.122-132

Indonesia. Undang-Undang Dasar Negara Republik Indonesia Tahun1945.

Indonesia. Undang-Undang Nomor 12 Tahun 2011 tentang Pembentukan Peraturan Perundang-Undangan.

Isharyanto. Hukum Kebijakan Ekonomi Publik. Yogyakarta: Thafa Media, 2016.

Jayus. "Merawat Semangat Kesatuan Dan Persatuan Dalam Kehidupan Bernegara." Jurnal Hukum Kenegaraan, Vol. II No. 1 (Juni 2019).

JA, Denny. Bahagia Itu Mudah dan IImiah. Depok: KataDepan, 2017.

Karianga, Hendra. Politik Hukum Dalam Pengelolaan Keuangan Daerah. Jakarta: Kencana Prenadamedia Group, 2013.

Kasim, Azhar. Reformasi Sempurna Melalui Dynamic Governance dalam Merekonstruksi Indonesia: Sebuah Perjalanan Menuju Dynamic Governance. Jakarta: PT. Kompas Media Nusantara, 2015.

Kusumaatmadja, Mochtar. Konsep-Konsep Hukum Dalam Pembangunan (Bandung: Alumni, 2004.

Lee, Yong-Shik. "General Theory of Law and Development." Cornel International Law Journal Vol. 50 Number 3 Fall 2017.

I Gusti Agung Oka Mahangga, I Gusti Agung Oka et al. "Peran dan Kendala Pemulihan Pariwisata Bali Pascabom (Suatu Kasus Disparda Provinsi Bali)." Analisis Pariwisata Vol. 12 No. 1 (tanpa bulan terbit 2012).

MD, Moh. Mahfud. Politik Hukum di Indonesia. Jakarta: PT. RajaGrafindo Persada, 2012.

Mutia, Muhammad Aziz Ali. Strategi Kebijakan Investasi Dalam Industri 4.0: Restriksi Di Sektor Telekomunikasi.Prosiding 2.0 KNIA Konferensi Nasional IImu Administrasi STIA LANBandung. Bandung: STIA LAN, 2018.

Panjaitan, Marojahan JS. Penyelesaian Penyalahgunaan Wewenang yang Menimbulkan Kerugian Negara Menurut Hukum
Administrasi Pemerintahan, Jurnal Hukum Ius Quia lustum, No. 3. Vol. 24 (Juli 2917).

https://doi.org/10.20885/iustum.vol24.iss3.art5

Politik, Hak Asasi Manusia, dan Demokrasi Dalam Bingkai Negara Kesejahteraan dan Kebahagiaan Menurut UUD 1945. Bandung: Pustaka Reka Cipta, 2018.

Tata Kelola Pemerintahan Yang Baik dalam Menghadapi Era Revolusi Industri 4.0 dan Society 5.0. Laporan Penelitian Perorangan Sekolah Tinggi Hukum Bandung Semester Genap Tahun Akademik 2018-2019. Bandung: STHB, 2019.

Pontoh, Zaenab dan M. Farid. "Hubungan Antara Religiusitas dan Dukungan Sosial dengan Kebahagiaan Pelaku Konversi Agama." Pesona: Jurnal Psikologi Indonesia Vol. 01 (Januari 2015). https://doi.org/10.30996/persona.v4i1.495

Putri, Endrika Widdia. "Konsep Kebahagiaan Dalam Perspektif AlFarabi." Jurnal Thaqafiyyat Vol.19 No.1 (Juni 2018). https://doi.org/10.34005/tahdzib.v1i2.443

Riwanto, Agus. "Politik Hukum Penguatan Fungsi Negara Untuk Kesejahteraan Rakyat Menurut UUD 1945," Jurnal Hukum dan Peradilan Vol. 6 No. 3 (November 2017). https://doi.org/10.25216/JHP.6.3.2017.337-360

Rynbrandt, Ryan. "The Pursuit of Happiness." Paper Prepared for the Western Political Science Association 2016 Annual Conference in San Diego, California March 25, 2016. San Diego, California: 2016.

Setiyono, Budi. Model \& Desain Negara Kesejahteraan. Bandung: Nuansa Cendika, 2018.

Sidharta, B. Arief. Ilmu Hukum Indonesia. Bandung: Unpar Press, 2016.

Soemantri, Sri. Hukum Tata Negara Indonesia Pemikiran dan Pandangan. Bandung: PT. Remadja Rosdakarya, 2014.

Surbakti, Ramlan, Demokrasi dan Nomokrasi dalam Problematika Hukum \& Peradilan di Indonesia. Jakarta: Sekretariat Jenderal Komisi Yudisial Republik Indonesia, 2014.

Trading Economic. "Ghana - Pertumbuhan PDB". https://id. trading economics. com/ ghana/gdp-growth-annual. Diakses 22 Agustus 2019.

"PDB Per Kapita - Daftar Negara - G20 "https://id.Tradingeconomics.com/country-list/gdp-percapita?continent=g20. Diakses 6 Agustus 2019.

The Indonesian Institute Center For Public Reasearch. "Teror Bom Jakarta dan Optimisme Perekonomian." Update Indonesia Vol. X No.2 (Januari 2016).

Triguna, IBG Yudha. "Konsep Ketuhanan dan Kemanusiaan Dalam Hindu." Jurnal Dharmasmrti Vol. I No. 18 (Mei 2018). https://doi.org/10.32795/ds.v1i18.104

Wahjono, Padmo. Indonesia Negara Berdasarkan Atas Hukum. Jakarta: Ghalia Indonesia, 1986.

Wattimena, Reza A.A. Bahagia, Kenapa Tidak. Yogyakarta: Maharsa, 2015.

Wolin, Sheldon S. Democracy Incorporated: Managed Democracy and The Specter of Inverted Totalitarianism. Princeton, New Jersey: Princeton University Press, 2008.

World Economic Forum. The Inclusive Development Index 2018 Summary and Data Highlights. Swiss: WEF, 2018.

\section{Received on 05-01-2021 \\ DOI: https://doi.org/10.6000/1929-4409.2021.10.57}

Accepted on 28-01-2021

Published on 03-02-2021

(C) 2021 Marojahan JS Panjaitan; Licensee Lifescience Global.

This is an open access article licensed under the terms of the Creative Commons Attribution Non-Commercial License (http://creativecommons.org/licenses/by-nc/3.0/) which permits unrestricted, non-commercial use, distribution and reproduction in any medium, provided the work is properly cited. 